DOI: https://doi.org/10.24127/ajpm.v8i1.1749

\title{
PENGEMBANGAN ALAT PERAGA LOGIKA MATEMATIKA MINIATUR TANDON AIR TINGKAT TIGA MELALUI REALISTIC MATHEMATICS EDUCATION (RME)
}

\author{
Septia Ezy Pratama ${ }^{1}$, Yahya AD $^{2}$, Dona Dinda Pratiwi ${ }^{3}$ \\ 1,2,3 Pendidikan Matematika, Universitas Islam Negeri Raden Intan Lampung \\ E-mail: $\quad$ septiaezypratama@radenintan.co.id $^{1)}$ \\ Yahyaagya59@gmail.com ${ }^{2}$ \\ donadinda@radenintan.ac.id $^{3)}$
}

Received 20 December 2018; Received in revised form 5April 2019; Accepted 3 May 2019

\begin{abstract}
This study aims to develop mathematical logic teaching aids through realistic mathematics education that is feasible, valid and effective so that students can find knowledge directly. This type of research is development research (Reseacrh and Development / R\&D) with the ADDIE development model with subjects namely mathematics education students at UIN Raden Intan Lampung. The research data was obtained by interview techniques and questionnaires. The results of the study show that the props developed by the researcher in the form of this application have been declared valid by experts who test the material aspects and aspects of the media; declared interesting based on research on small group trials by 3 students and also 10 students in a large group trial by purposive sampling; and has effectiveness in the high category based on the results of field tests in 1 class of students who have just taken a mathematics logic course.
\end{abstract}

Keywords: Mathematical logic; miniature water reservoirs; props; realistic mathematics education.

\section{PENDAHULUAN}

Kemajuan teknologi merupakan sesuatu yang tidak bisa dihindari dalam kehidupan saat ini, seperti adanya berbagai aplikasi yang dapat memudahkan aktivitas gerak manusia, kemajuan teknologi selalu beriringan dengan kemajuan ilmu pendidikan.Wijayanti\& Sungkono (2017:102) mengemukakan bahwailmu pendidikan pada hakikatnyamerupakan ilmu yang dikonstruksi, dikembangkan, dan diterapkan dalam pendidikan. Mengembangkan suatu ilmu pendidikan juga harus melihat tujuan yang ingin dicapai dalam pembelajaran, salah satu yang menunjang dalam tercapainya tujuan pembelajaran adalah adanya sebuah media pembelajaran.
Media pembelajaran yang biasa digunakan salah satunya yaitu alat peraga. Menurut Sudjana alat peraga merupakan media pembelajaran yang mengandung atau membawakan ciriciri dan konsep yang dipelajari Oktiana (2015:388). Alat peraga adalah salah satu komponen penentu efektivitas belajar, karena alat peraga dapat mengubah materi ajar yang abstrak menjadi kongkrit dan realistik (Yulianti, Eni, Zulkardi, 2010). Sebagaimana fungsi utama dari alat peraga yaitu menurunkan keabstrakan dari konsep dan penggunaan alat peraga ini diutamakan pula agar hasil belajar yang dicapai akan tahan lama diingat peserta didik.

Pada dunia pendidikan terdapat salah satu mata pelajaran yang dikenal abstrak yaitu matematika.Pada ilmu 
matematika konsep yang ada bersifat hierarkis. Salah satu kemampuan peserta didik yang diharapkan yaitu mampu memahami konsep matematika, menjelaskan keterkaitan antar konsep, dan mengaplikasikan konsep secara luwes (Husna, Dwina, \& Murni, 2014). Peranan matematika juga sangat penting sebagai dasar logika atau penalaran (Nugroho, Putra, Putra, \& Syazali, 2017). Logika matematika adalah mata kuliah yang berhubungan dengan seluruh jenis penalaran juga pembuktian matematika (Manongga \& Nataliani, 2013). Penalaran sendiri merupakan salah satu kegiatan berfikir manusia untuk menarik kesimpulan yang sah, dirumuskan ke dalam bentuk pernyataan-pernyataan, baik pernyataan tunggal maupun majemuk, dan disusun berdasarkan kaidah tertentu (Susilo, 2012).

Pembelajaran saat ini masih didominan dengan sistem belajar konvensional, peserta didik belajar menggunakan buku paket dan hanya mencatat apa yang diberikan oleh pendidik saja, meski kemampuan peserta didik dinlilai baik namun perlu adanya suasana belajar baru dengan memanfaat teknologi yang dapat membuat peserta didik belajar lebih aktif. Selain itu pendidik belum menemukan adanya alat peraga yang dapat membuktikan kebenaran dan menggambarkan konsep dari materi tabel kebenaran pada logika matematika dan banyaknya mahasiswa yang menanyakan keterkaitan materi dengan kehidupan sehari-hari, hal ini berdasarkan pra penilitian yang dilakukan di UIN Raden Intan Lampung.

Pada pembuktian tabel kebenaran logika matematika masih terdapat mahasiswa yang menjawab soal dengan kurang tepat. Sehingga, dapat dikatakan masih kurangnya pemahaman mahasiswa pada materi logika matematika. Hal ini senada dengan pendapat Netriwati pada penelitiannya yang menggunakan rangkaian listrik pada materi logika matematika, hasil pengamatannya menunjukan belum semua mahasiswa mampu memiliki daya nalar yang baik, hal ini disebabkan karena mahasiswa hanya menghafal tabel kebenaran yang diberikan oleh pendidik saja tanpa ada pembuktian yang jelas (Netriwati, 2015). Hal ini pun dibenarkan dengan pendapat (Suandito, 2017)tentang pentingnya suatu pembuktian dan motivasi mendasar mengapa orang perlu membuktikan suatu pernyataan matematika, yaitu untuk meyakinkan bahwa apa yang selama ini dianggap benar adalah memang benar. Jika dalam pembelajaran hanya menggunakan fakta yang sudah tertulis dalam buku atau teks, maka disini perlu adanya suatu pemahaman yaitu suatu bukti yang tidak hanya membuktikan suatu fakta, tetapi juga memberikan penjelasan tentang fakta tersebut.

Peran pendidik juga bukan sekedar pemberi informasi saja, tetapi pendidik harus mampu mendorong agar peserta didik dapat lebih bereksplorasi, serta menemukan pengetahuan kembali secara langsung (Netriwati, 2015). Dari hal tersebut dibutuhkan suatu pendekatan pembelajaran yang sesuai dengan keabstrakan materi, yaitu pendekatan Realistic Mathematics Education (RME).Freudenthal mengembangkan suatu pendekatan teoritis dengan menggabungkan pandangan apa itu matematika, bagaimana peserta didik belajar matematika, dan bagaimana matematika harus diajarkan. Peserta didik tidak boleh dipandang pasif, tapi peserta didik harus menemukan 
kembali matematika dengan cara mereka sendiri di bawah bimbingan pendidik (Suandito, 2017).

Pembelajaran kontekstual dengan RME dapat membantu pendidik mengaitkan situasi pada dunia nyata dengan materi yang diajarkan, serta peserta didik mampu menghubungkan pengetahuan yang dimiliki dengan penerapan dalam kehidupan sehari-hari (Susanti, 2015). Sesuai dengan hal tersebut maka dapat digunakan alat peraga yang mampu menjelaskan pembuktian pada materi logika matematika, yaitu sebuah alat peraga berupa miniatur tandon air tingkat tiga.Tandon air sendiri adalah suatu tempat atau wadah untuk menampung air yang kemudian air tersebut dialirkan melalui saluran atau keran.

Sebelumnya telah ada alat peraga berupa miniatur tandon air yang digunakan pada tingkat SMA di kota Manna, namun materi yang dijelaskan masih sangat sederhana dalam bentuk tandon yang terpisah. Pada penelitian ini tandon air tersebut dikembangkan menjadi lebih kompleks baik dari segi materi maupun bentuk dari tandon air tersebut dan disajikan dalam bentuk aplikasi. Miniatur tandon air tingkat tiga ini merupakan suatu alat peraga yang dirancang dalam skala kecil namun memiliki bentuk dan proses cara kerja seperti tandon air yang berukuran besar (Budi, 2008). Alat peraga ini dibuat tiga tingkatan karena sesuai dengan materi logika matematika yang akan dijelaskan, yaitu konjungsi, disjungsi, implikasi, biimplikasi serta tautologi dan kontradiksi agar mempermudah peserta didik memahami darimana rumus atau konsep didapat dengan mengalami secara langsung dan menghubungkannya dengan benda nyata.
Berdasarkan permasalahan di atas, maka penelitian ini dilaksanakan dengan tujuan untuk mengembangan alat peraga miniatur tandon air tingkat tiga melalui Realistic Mathematics Education (RME) agar mahasiswa dapat belajar lebih aktif dengan membangun konsep dan pengetahuannya sendiri dalam memahami materi serta memanfaatkan teknologi yang ada saat ini sehingga alat peraga tersebut disajikan dalam bentuk aplikasi agar fleksibel dapat digunakan dimana saja dan kapan saja oleh mahasiswa dan memberi suasana belajar baru dan lebih bermakna.

\section{METODE PENELITIAN}

Jenis penelitian yang dilakukan adalah penelitian dan pengembangan (researh and developmen /R\&D) Menurut Sugiyono R\&D adalah metode penelitian yang digunakan untuk menghasilkan suatu produk tertentu dan menguji keefektifan produk tersebut. Tujuan dari metode ini agar digunakan untuk menghasilkan produk tertentu dalam menguji keefektifan dan kebermanfaatan produk terhadap produk yang dikembangkan (Sugiyono, 2014). Selain itu, penelitian ini menggunakan model ADDIE. Model pengembangan ADDIE ini dikembangkan oleh Branch berupa model pengembangan berbasis produk, terdapat lima langkah penelitian yang dilaksanakan yaitu analyze, design, develop, implement, dan evaluate. Model ini memiliki langkah sistematis, detail, dan menghasilkan produk dengan mengaplikasikan konteks yang spesifik (Sari, Amin, \& Lukiati, 2017).

Penelitian ini dilaksanakan di UIN Raden Intan Lampung.Tim validasi kelayakan produk dalam penelitian ini 
adalah beberapa dosen pendidikan matematika di UIN Raden Intan Lampung.Subjek untuk mengetahui kemenarikan produk adalah 3 mahasiswa pada uji coba kelompok kecil dan 10 mahasiswa diuji coba kelompok besar yang telah menempuh mata kuliah logika matematika dan dipilih secara purposive sampling. Selain itu subjek untuk menilai efektivitas dari produk yang telah selesai divalidasi dan revisi yaitu 1 kelas mahasiswa yang baru saja menempuh mata kuliah logika matematika. Teknik pengumpulan data dalam penelitian ini menggunakan teknik wawancara, observasi, angket dan tes. Wawancara dilakukan kepada dosen pengampu saat tahap analisis, observasi dilakukan untuk melihat proses pembelajaran saat melakukan pra penelitian dan penelitian dilapangan saat uji coba produk. Sedangkan angket yang digunakan berupa angket validasi yang diisi oleh 3 ahli materi dan 3 ahli media saat pelaksanaan validasi serta angket respon mahasiswa yang diisi saat uji coba dan uji lapangan pada mahasiswa dengan menggunakan skala likert. Tes adalah teknik pengumpulan data akhir yang dilakukan dengan memberikan soal pretest dan posttest saat uji coba kepada mahasiswa. Hasil dari tes tersebut digunakan untuk melihat hasil belajar dan nilai efektivitas dari produkyang dikembangkan dengan menggunakan perhitungan nilai $N$ Gain sebagai berikut:

$$
N-\text { Gain }=\frac{(\text { Skor posttest }- \text { skor pretest })}{(\text { Skor maksimal-skor pretest })}
$$

Hasil perhitungan gain kemudian diinterpretasikan dengan menggunakan klasifikasi dari Hake seperti pada Tabel 1.
Tabel 1. Kategori Hasil Perhitungan $N$ -

\begin{tabular}{ccc} 
Gain & \\
\hline No & $\begin{array}{c}\text { Kriteria } \\
\text { pencapaian nilai }\end{array}$ & $\begin{array}{c}\text { Tingkat } \\
\text { Efektivitas }\end{array}$ \\
\hline 1 & $N$-Gain $>0,7$ & Tinggi \\
2 & $0,3<N$-Gain $\leq 0,7$ & Sedang \\
3 & $N$-Gain $\leq 0,3$ & Rendah \\
\hline & & $($ Hake, $1999: 1)$
\end{tabular}

\section{HASIL PENELITIAN DAN PEMBAHASAN}

Produk yang dihasilkan pada penelitian dan pengembangan adalah sebuah aplikasi media pembelajaran berupa alat peraga logika matematika miniatur tandon air tingkat tiga melalui Realistic Mathematics Education (RME). Penelitian dan pengembangan menggunakan prosedur pengembangan ADDIE yang terdiri dari 5 tahap yaitu: analyze, design, develop, implement, dan evaluate. Hasil dari tiap tahapan dapat dilihat sebagai berikut:

\section{Analyze (Tahap Analisis)}

Hasil analisis digunakan sebagai pedoman dan pertimbangan dalam penyusunan aplikasi alat peraga miniatur tandon air tingkat tiga. Analisis kebutuhan yang dilakukan berupa wawancara dosen dan pengisian angket mahasiswa. Berdasarkan hasil observasi pada pembelajaran logika matematika, tenaga pendidik hanya menggunakan media cetak atau buku paket saat pembelajaran. Memanfaatkan media cetak saja akan membuat mahasiswa pasif dalam belajar.Sedangkan mahasiswa hanya belajar dengan teknik menghapal tanpa membuktikan kebenaran rumus yang ada serta keterkaitan dengan dunia nyata. Sehingga dibutuhkan media pembelajaran baru dengan memanfaatkan teknologi agar mahasiswa dapat belajar lebih aktif dan 
memiliki daya ingat yang baik terhadap materi yang dipelajari.

\section{Design (Tahap Perancangan)}

a. Penyusunan desain media

Media pembelajaran berbentuk aplikasi android berupa alat peraga miniatur tandon air tingkat tiga ini dibuat dengan menggunakan program utama Construct 2. Selain itu, pembuatan media ini juga menggunakan program pendukung yaitu Corel Draw X4 dan Adobe Photoshop CS6. Media ini dijalankan menggunakan smarthphone android; Operation System Android minimum versi 4.0 (Jelly Bean); font 14 pt; jenis huruf Times New Roman. Penyusunan desain media ini dimulai dengan menyusun kerangka yang terdiri dari bagian awal, bagian isi media, dan bagian penutup.

\section{b. Perancangan Instrumen}

Instrumen yang digunakan berupa angket (kuesioner) yang disusun untuk mengevaluasi media yang telah dibuat. Instrumen penilaian kualitas produk yang telah dikembangkan berupa angket daftar isian (check list) untuk ahli materi, ahli media dan mahasiswa.

\section{Development(Tahap}

\section{Pengembangan)}

a. Pembuatan Draft Media

Draft media yang disesuaikan dengan pendekatan RME dikembangkan menjadi media dengan rancangan sebagai berikut:

1) Splash Screen

Splash Screen atau tampilan pertama program sebelum masuk ke dalam bagian awal.

2) Menu Utama

Menu utama adalah tampilan yang berisi berbagai menu untuk bagian isi.

a) Sejarah Logika Matematika

Pada menu ini berisi beberapa layer yang menjelaskan sejarah dari logika matematika, mulai dari pemikiran para ahli serta kaitan materi dengan air yang juga menjadi dasar dalam pembuatan alat peraga dengan background yaitu ka'bah sehingga menggambarkan nuansa islami.

b) Materi

Pada menu ini berisi beberapa layer yang menjelaskan materi beberapa simbol logika matematika, yaitu terdiri dari negasi, konjungsi, disjungsi, implikasi, biimplikasi, tautologi dan kontradiksi serta sumber rujukan materi tersebut agar mahasiswa dapat mempelajari materi ini dengan mudah dan dapat dipelajari dimanapun dan kapanpun.

\section{c) Alat Peraga}

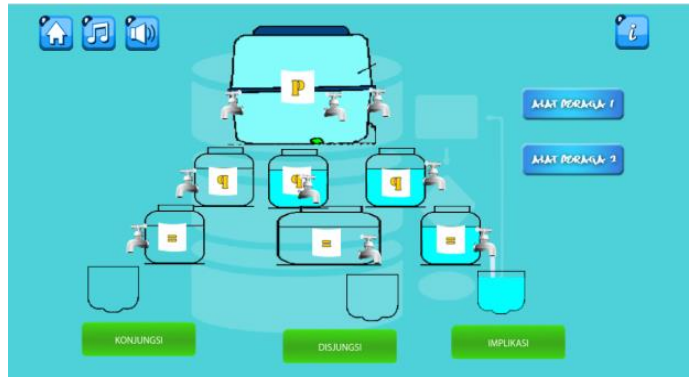

Gambar 1. Tampilan Alat Peraga Tandon Air Tingkat Tiga

Melalui pendekatan Realistic Mathematics Education (RME) alat peraga pada Gambar 1 ini didesain dengan mengaitkan materi dengan kehidupan seharihari. Alat peraga ini bertujuan agar mahasiswa dapat menemukan kembali dan mengontruksi ilmu pengetahuan yang dipelajari sehingga mahasiswa lebih mudah menerima dan mengingat materi. 
DOI: https://doi.org/10.24127/ajpm.v8i1.1749

d) Soal

Disajikan beberapa tampilan soal berupa tabel kebenaran, dengan adanya soalsoal latihan ini bertujuan menguji daya ingat mahasiswa terhadap pemahaman materi masing-masing simbol logika yang telah dipelajari.

e) Tentang

Pada menu tentang berisi profil yang terdiri dari logo instansi, judul penelitian, nama, prodi, institusi, tempat tanggal lahir dan e-mail.

b. Validasi Produk

Validasi dimaksudkan untuk meminta masukan dan pertimbangan dari para ahli yaitu ahli materi dan ahli media terhadap produk yang dibuat.

Adapun hasil dari validasi ahli materi sebagai berikut:

1) Hasil Validasi Ahli Materi

$$
\text { Validasi ahli materi }
$$
bertujuan untuk menguji kelengkapan materi, kebenaran materi dan sistematika dari materi. Perbandingan hasil validasi ahli materi pada tahap 1 dan tahap 2 dapat dilihat juga pada Gambar 2.

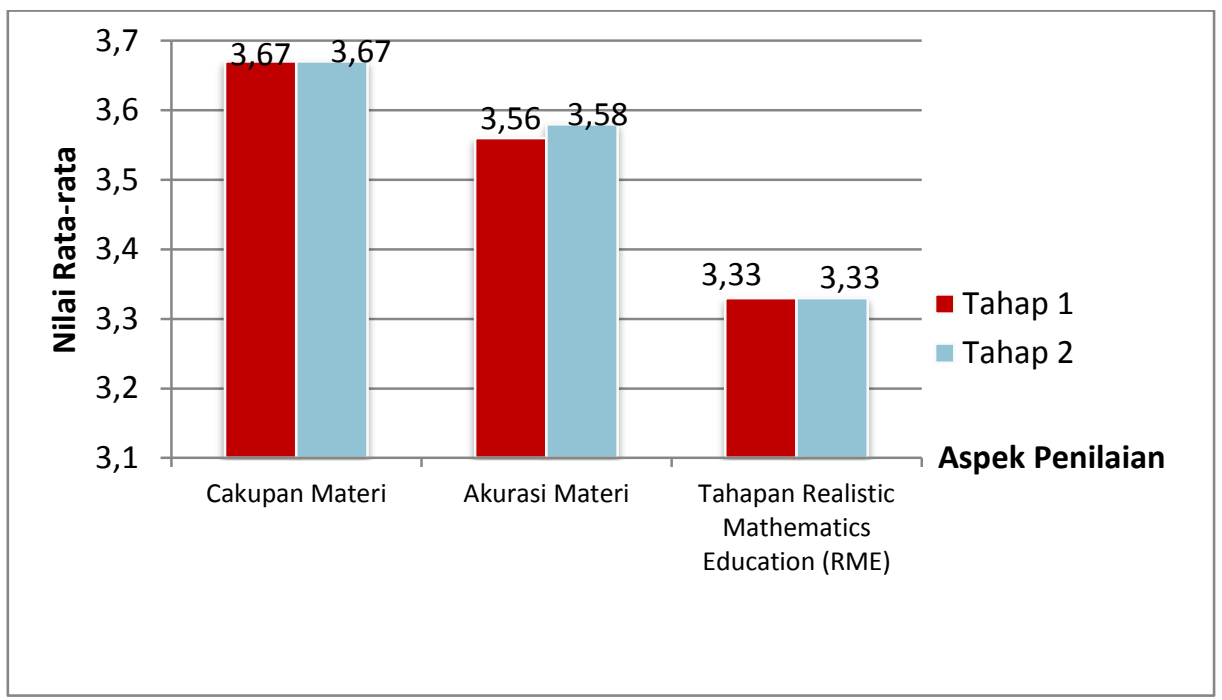

Gambar 2. Perbandingan Hasil Validasi Ahli Materi Tahap 1 dan Tahap 2.

Dari Gambar 2 perbandingan hasil validasi ahli materi tahap 1 dan tahap 2 terlihat bahwa terdapat peningkatan pada aspek akurasi materi dari tahap 1 ke tahap 2 dan dari ketiga aspek tersebut telah valid sehingga media yang dihasilkan sudah layak digunakan.
2) Hasil Validasi Ahli Media

Validasi ahli media bertujuan untuk menguji penyajian media berupa alat peraga berbentuk aplikasi.Perbandingan hasil validasi ahli media pada tahap 1 dan tahap 2 dapat dilihat juga pada Gambar 3. 
DOI: https://doi.org/10.24127/ajpm.v8i1.1749

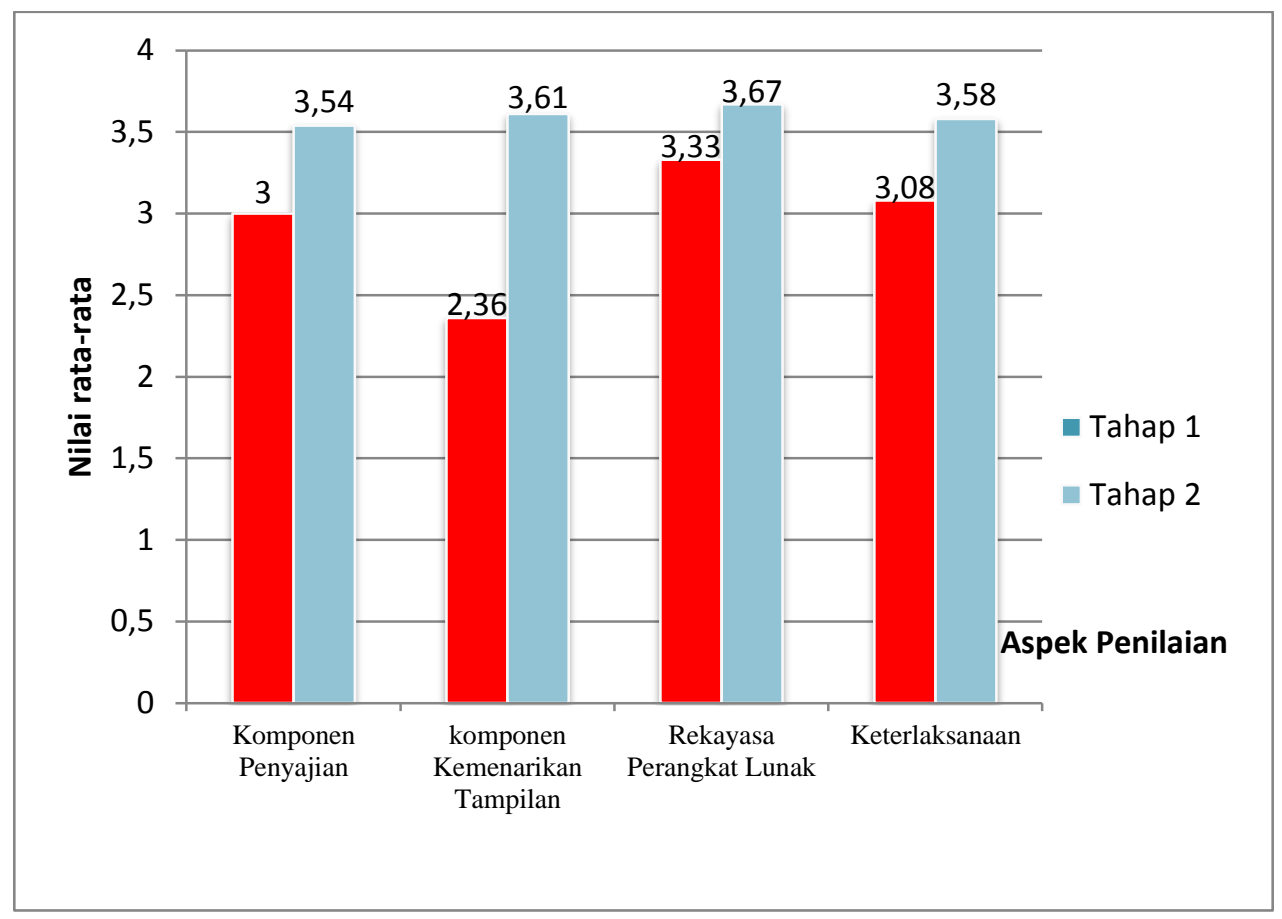

Gambar 3. Perbandingan Hasil Validasi Ahli Media Tahap 1 dan Tahap 2.

Dari Gambar 3 terlihat grafik perbandingan hasil validasi ahli media tahap 1 dan tahap 2 bahwa terdapat peningkatan yang sangat baik pada seluruh aspek dan telah memiliki kriteria valid sehingga media yang dihasilkan sudah layak digunakan.

c. Revisi Pembuatan Produk

Adapun saran/masukan untuk perbaikan produk adalah pada Gambar 4- 8.

1) Saran/Masukan Ahli Materi

\section{Tampilan Produk}

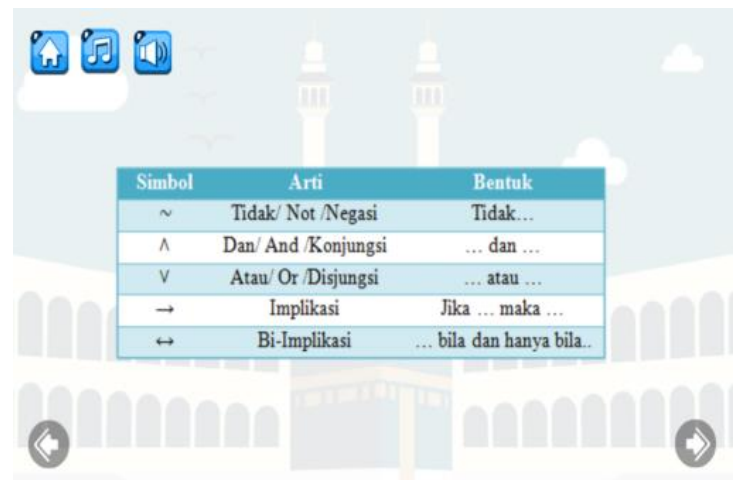

Gambar 4. Tabel arti dan simbol logikaMatematika. 
DOI: https://doi.org/10.24127/ajpm.v8i1.1749

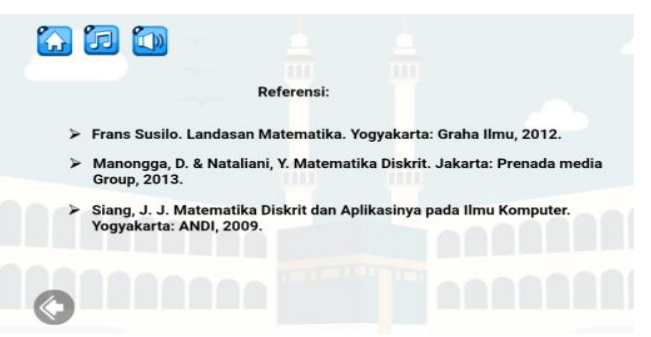

Gambar 5. Tampilan sumber rujukan/referensi.

2) Saran/Masukan Ahli Media

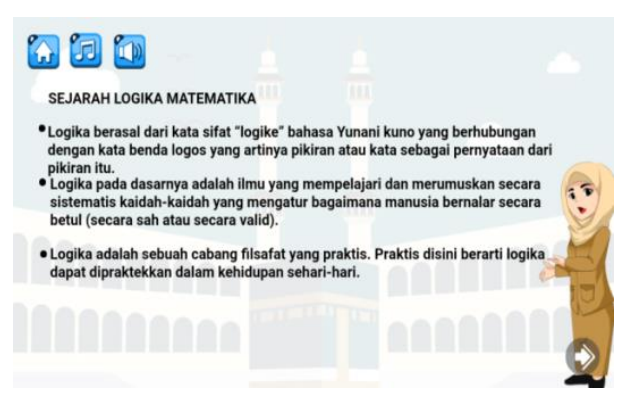

Gambar 6. Tampilan materi.

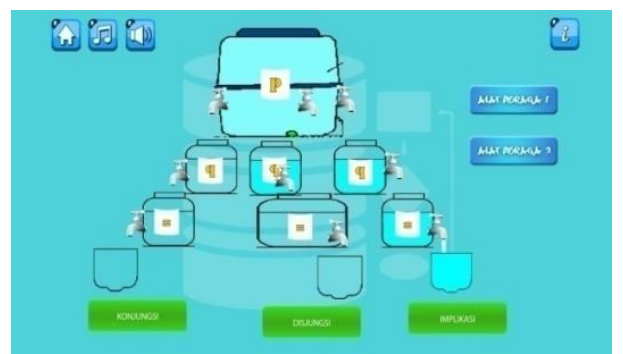

Gambar 7. Kerangka tandon air tingkat tiga.

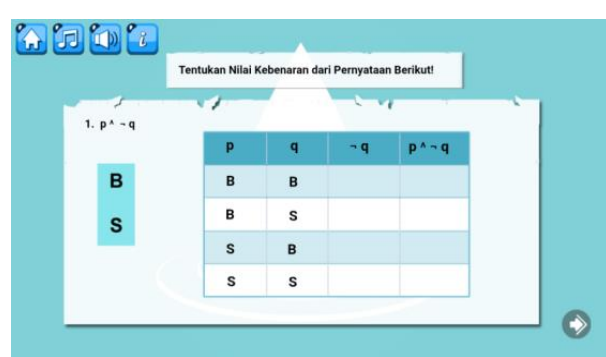

Gambar 8. Tampilan soal tabel kebenaran.

\section{Implementation}

\section{Implementasi)}

a. Uji Coba Kelompok Kecil

Uji coba ini dilakukan kepada 3 mahasiswa yang telah menempuh mata kuliah logika

\section{(Tahap}

matematika dengan dipilih secara purposive sampling untuk menguji kemenarikan dari produk aplikasi yang dikembangkan. Hasil uji coba dapat dilihat pada Tabel 2 . 
DOI: https://doi.org/10.24127/ajpm.v8i1.1749

Tabel 2. Hasil uji coba kelompok kecil.

\begin{tabular}{cccc}
\hline No. & Nama & $\begin{array}{c}\text { Jumlah } \\
\text { Skor }\end{array}$ & $\begin{array}{c}\text { Skor } \\
\text { Kelayakan }\end{array}$ \\
\hline 1 & Dwi Agus Pramono & 39 & 3,25 \\
2 & Melvi Adistia & 41 & 3,42 \\
3 & Ida Oktarida & 40 & 3,33 \\
\hline & JUMLAH & $\mathbf{1 2 0}$ & $\overline{\boldsymbol{x}}=\mathbf{3 , 3 3}$
\end{tabular}

Sumber Data : Diolah dari Hasil Angket Penilaian Uji Coba Kelompok Kecil

Berdasarkan analisis pada Tabel 2 hasil uji coba kelompok kecil diperoleh rata-rata 3,33 dengan kriteria interpretasi yang dicapai yaitu "Sangat Menarik".

b. Uji Coba Kelompok Besar

Pada uji kelompok besar ini produk yang telah dibuat diuji cobakan kepada 10 mahasiswa yang telah menempuh mata kuliah logika matematika dengan dipilih secara purposive sampling menurut data hasil ujian mahasiswa oleh dosen pengampu. Hasil uji coba dapat dilihat pada Tabel 3.

Tabel 3. Hasil uji coba kelompok besar.

\begin{tabular}{cccc}
\hline No. & Nama & $\begin{array}{c}\text { Jumlah } \\
\text { Skor }\end{array}$ & $\begin{array}{c}\text { Skor } \\
\text { Kelayakan }\end{array}$ \\
\hline 1 & Ahmad Safi'i & 47 & 3,92 \\
2 & Dewi Lestari & 40 & 3,33 \\
3 & Guswita Anggraini & 45 & 3,75 \\
4 & Luthvia Rohmaini & 43 & 3,58 \\
5 & Nadila Aysahni & 39 & 3,25 \\
6 & Riska Restiana & 40 & 3,33 \\
7 & Ru'yatul hasanah & 39 & 3,25 \\
8 & Tri Desi Retnosari & 36 & 3,00 \\
9 & Veroni Radin Nadila & 36 & 3,00 \\
10 & Yuliana & 37 & 3,08 \\
\hline & JUMLAH & $\mathbf{4 0 2}$ & $\overline{\boldsymbol{x}}=\mathbf{3 , 3 5}$ \\
\hline
\end{tabular}

Sumber data : diolah dari hasil angket penilaian uji coba kelompok besar

Berdasarkan pada Tabel 3 hasil uji coba kelas besar dipeoleh data rata-rata 3,35 dengan kriteria interpretasi yang dicapai yaitu "Sangat Menarik", dengan hal ini berarti aplikasi alat peraga yang dikembangkan dapat digunakan sebagai media belajar mahasiswa pada matakuliah logika matematika.

\section{c. Uji Efektivitas}

Pada tahap ini aplikasi alat peraga tersebut diuji cobakan ke mahasiswa yang yang baru menempuh mata kuliah logika matematika dengan memberikan soal pretest dan posttest pada mahasiswa dengan tujuan untuk melihat apakah produk yang telah dibuat sudah efektif untuk diterapkan dalam pembelajaran. Adapun hasil 
DOI: https://doi.org/10.24127/ajpm.v8i1.1749

perhitungan pretest dan posttest dapat dilihat pada Tabel 4. Rekapitulasi nilai

$N$-gain dapat dilihat pada Tabel 5.

Tabel 4. Hasil Perhitungan Pretest dan Posttest.

\begin{tabular}{cccccc}
\hline & N & $\begin{array}{c}\text { Skor } \\
\text { Ideal }\end{array}$ & $\begin{array}{c}\text { Skor } \\
\text { Minimum }\end{array}$ & $\begin{array}{c}\text { Skor } \\
\text { Maksimum }\end{array}$ & Xbar \\
\hline Pretest & 23 & 100 & 65 & 90 & 83,26 \\
Posttest & 23 & 100 & 85 & 100 & 95,65 \\
\hline
\end{tabular}

Tabel 5. Rekapitulasi Nilai N-Gain.

\begin{tabular}{ccccccc}
\hline \multirow{2}{*}{ No } & Kelas & n & \multicolumn{4}{c}{ Nilai } \\
\cline { 4 - 7 } & & $\begin{array}{c}\text { Skor } \\
\text { Ideal }\end{array}$ & $\begin{array}{c}\text { Skor } \\
\text { Minimum }\end{array}$ & $\begin{array}{c}\text { Skor } \\
\text { Maksimum }\end{array}$ & $\begin{array}{c}\text { Rata-rata } \\
\text { N-gain }\end{array}$ \\
\hline 1 & Kelas A Semester 3 & 23 & 100 & 0,333 & 1 & 0,800 \\
\hline
\end{tabular}

Berdasarkan data yang diperoleh pada Tabel 4 dan Tabel 5 dapat dilihat nilai minimum, nilai maksimum dan nial dari rata-rata $N$-gain. Hasil nilai minimum dari prestest dan posttest adalah 0,333 dan nilai maksimum dari pretest dan posttest adalah 1 sedangkan nilai rata-rata $N$-Gain pada prestest dan posttest adalah 0,800 dan termasuk dalam kategori tinggi.

\section{Evaluation (Tahap Evaluasi)}

Evaluasi dilakukan oleh peneliti pada semua tahapan yaitu untuk menganalisis data hasil penelitian yang diperoleh yaitu analisis kebutuhan awal, penyusunan desain, kevalidan media dan materi dari para ahli serta hasil angket respon mahasiswa.

Produk yang dikembangkan ini berupa alat peraga miniatur tandon air yang terdiri dari tiga tingkatan yang menjelaskan materi tabel kebenaran pada mata kuliah logika matematika.Kelebihan dari produk ini karena materi dimuat dengan pendekatan Realistic Mathematics Education (RME) sehingga mahasiswa lebih mudah dalam memahami materi, selain itu alat peraga disajikan dalam bentuk aplikasi sehingga dapat digunakan secara fleksibel. Sedangkan kekurangan produk yaitu materi hanya terbatas pada kalimat penghubung, tautologi dan kontrakdisi saja.

Penelitian ini sejalan
dengan penelitian yang dilakukan oleh Fredi Ganda Putra (2016) dan Sarah Wahyu Susanti (2015) yang mengatakan bahwa pembelajaran dengan menggunakan pendekatan RME lebih baik dari model pembelajaran langsung serta penelitian Rahmad Ramelan Setia Budi (2008) menjelaskan bahwa penerapan pendidikan matematika realistik Indonesia atau RME dengan alat peraga praktik miniatur tandon air terbukti lebih efektif dalam meningkatkan hasil belajar matematika peserta didik 
dibanding alat peraga charta rangkaian seri paralel.

\section{KESIMPULAN DAN SARAN}

Berdasarkan penelitian yang telah dilakukan pada pengembangan alat peraga logika matematika miniatur tandon air tingkat tiga melalui Realistic Mathematics Eduation dapat disimpulkan bahwa alat peraga yang telah dikembangkan dinyatakan valid oleh para ahli yang menguji 2 aspek yaitu aspek materi dan aspek media yang merupakan dosen Pendidikan Matematika di UIN Raden Intan Lampung; dinyatakan menarik berdasarkan hasil penelitian uji coba kelompok kecil oleh 3 mahasiswa dan 10 mahasiswa pada uji coba kelompok besar; serta memiliki efektivitas dalam kategori tinggi berdasarkan uji efektivitas dilapangan pada mahasiswa Pendidikan Matematika di UIN Raden Intan Lampung.

Adapun saran yang dapat diberikan untuk pengembangan alat peraga iniyaitu media pembelajaran alat peraga logika matematika ini perlu disempurnakan kembali, karena materi yang disajikan hanya terbatas pada tabel kebenaran saja. Sehingga diharapkan dapat dilakukan pengembangan pada materi yang lain sesuai dengan kebutuhan kampus masing-masing agar pembelajaran dapat lebih aktif dan bermakna.

\section{DAFTAR PUSTAKA}

Budi, R. R. S. (2008). Penerapan Pendidikan Matematika Realistik Indonesia Melalui Penggunaan Alat Peraga Praktik Miniatur Tandon Air Terhadap Hasil Belajar Siswa Di Kelas X Sma Negeri 3 Kota Manna. Jurnal Pendidikan Matematika, 2(1), 63-80.
Husna, F. El, Dwina, F., \& Murni, D. (2014). Penerapan Strategi React Dalam Meningkatkan Kemampuan Pemahaman Konsep Matematika Siswa Kelas X Sman 1 Batang Anai. Jurnal Pendidikan Matematika, 3(1), 26-30.

Manongga, D., \& Nataliani, Y. (2013). Matematika Diskrit. Jakarta: Prenadamedia Group.

Netriwati. (2015). Meningkatkan Kemampuan Berfikir Logis Matematis Mahasiswa dengan Menggunakan Rangkaian Listrik pada Materi Logika di IAIN Raden Intan Lampung. Al-Jabar: Jurnal Pendidikan Matematika, 6(1), 7580.

Nugroho, A. A., Putra, R. W. Y., Putra, F. G., \& Syazali, M. (2017). Pengembangan Blog Sebagai Media Pembelajaran Matematika. Al-Jabar: Jurnal Pendidikan Matematika, 8(2), 197-204.

Oktiana, T. (2015). Pengembangan Alat Peraga Lingkaran dengan Metode Penemuan Terbimbing Kelompok untuk Meningkatkan Komunikasi Matematis, 385-392.

Sari, A. P. P., Amin, M., \& Lukiati, B. (2017). Buku Ajar Bioteknologi Berbasis Bioinformatika Dengan Model ADDIE. Jurnal Pendidikan: Teori, Penelitian, Dan Pengembangan, 2(6), 768-772.

Suandito, B. (2017). Bukti Informal dalam Pembelajaran Matematika. Al-Jabar: Jurnal Pendidikan Matematika, 8(1), 13-23.

Sugiyono. (2014). Metode Penelitian Pendidikan. Bandung: Alfabeta.

Susanti, S. W. (2015). Eksperimentasi Model Pembelajaran RME, NHT Dan MPL Terhadap Hasil Belajar Siswa SMPN 3 Balikpapan, 733774. 
AKSIOMA: Jurnal Program Studi Pendidikan Matematika

DOI: https://doi.org/10.24127/ajpm.v8i1.1749

Susilo, F. (2012). Landasan Matematika. Yogyakarta: Graha Ilmu.

Wijayanti, S., \& Sungkono, J. (2017). Pengembangan Perangkat Pembelajaran mengacu Model Creative Problem Solving berbasis Somatic, Auditory, Visualization, Intellectually. Al-Jabar: Jurnal Pendidikan Matematika, 8(2), 101-110.

https://doi.org/http://dx.doi.org/10. 24042/ajpm.v8i2.1941

Yulianti, Eni, Zulkardi, A. S. R. (2010). Pengembangan Alat Peraga Menggunakan Rangkaian Listrik Seri-Paralel Untuk Mengajarkan Logika Matematika Di SMK Negeri 2 Palembang. Jurnal Pendidikan Matematika, 4(1), 2632. 